\title{
Induced Systemic Resistance through Organic Based IPM Module against Pest Infesting Chilli
}

\author{
A. Ravikumar ${ }^{1 *}$, S. Manisegaran ${ }^{2}$, C. Chinniah ${ }^{2}$ and V. Janahiraman ${ }^{1}$ \\ ${ }^{1}$ Krishna College of Agriculture and Technology, Usilampatty, India \\ ${ }^{2}$ Department of Agricultural Entomology, Agricultural College and Research Institute, Madurai, \\ Tamil Nadu Agricultural University, Tamil Nadu, India \\ *Corresponding author
}

\begin{tabular}{|l|}
\hline Ke y w o r d s \\
Chilli, Biochemical \\
constituents, Insect \\
pests, IPM modules, \\
Organic \\
amendments, Soil \\
microflora.
\end{tabular}

\section{A B S T R A C T}

Field experiments were undertaken to study the impact of three different IPM modules viz., Bio-intensive $\left(\mathrm{M}_{1}\right)$, recommended $\left(\mathrm{M}_{3}\right)$ and suggestive modules $\left(\mathrm{M}_{4}\right)$ in comparison with farmers practice $\left(\mathrm{M}_{2}\right)$ and control $\left(\mathrm{M}_{5}\right)$ for the management of major pests of chilli under irrigated conditions during December 2010 - May 2011 and August 2012 - January 2013. The study revealed that the Suggestive module $\left(\mathbf{M}_{4}\right)$ showed great impact not only against major pests of chilli viz., Scirtothrips dorsalis, Polyphagotarsonemus latus, Helicoverpa armigera and Spodoptera litura but also on the activity of natural enemies like Chrysopera carnea, Cheilomenes sexmaculatus, Coccinella septampunctata and Oxypes sp. The lowest population of major pests of chilli was found in Suggestive module $\left(\mathrm{M}_{4}\right)$ which indicates that integration of organic sources of nutrients and amendments [Farm yard manure, neem cake and biofertilizers (Azosphos, and silica solubilizing bacteria)] along with other eco - friendly management approaches (botanicals, biocontrol agents and Spinosad) would have efficiently managed all the major pests and registered less damage. Application of organic sources of nutrients altered the biochemical constituents of chilli plants that could be attributed to the enhanced defensive chemicals viz., phenols and silica content leading to induced resistance against pests of chilli, in addition less content of total chlorophyll and reducing sugars making the plants less prone to pest attack and found safer to natural enemies. It also enhanced the population of soil microflora which enhanced the mobilization of nutrients to the plant and in turn as increased yield.

\section{Introduction}

Chilli, Capsicum annum L. is one of the most important valuable crops in India, grown for its fruits. It is used as vegetables, spices and condiments and also got two important commercial qualities; one is red colour because of the pigment capsanthin, other one is known for biting pungency attributed by capsaicin which has got high medicinal value. It is also rich in vitamin A, C E and oleoresin content. India is the major, producer, exporter and consumer of chillies in the world and it is cultivated in an area of 7.75 lakh hectares with the production of 14.92 lakh tonnes (Anon., 2014). During 2014-15, Indian spices exports have been able to continue its increasing trend with 893,920 tonnes of spices, valued at Rs. 14899.68 crore has been exported from our country, Chilli accounting 
for 3,47,000 tonnes of total spices and fetches Rs. 3517.10 crore of rupees as foreign exchange (Supriya Lamba et al., 2015). A major part of chillies produced in India are consumed within the country and only 5 to 7 per cent are exported, all though it is cultivated all over India, its productivity is only $17.40 \mathrm{q} \mathrm{ha}^{-1}$ which is low when compared to other countries. Among the constraints in chilli cultivation, arthropod pests are the most important consequence, which significantly affect the production. A total of 57 species of insect and mite pests were recorded damaging chilli. Of these, the sucking pests like thrips, Scirtothrips dorsalis (Hood), mite, Polyphagotarsonemus latus (Banks) from seedling to fruiting stage and lepidopteran pests like fruit borers, Helicoverpa armigera (Hubner) and Spodoptera litura (Fabricus) during flowering and fruit formation stages are the major pests, responsible for causing considerable yield loss (Rajaram, 1998).

The control of insect and other pests in chilli was achieved mainly with application of synthetic pesticides. Despite its relative efficiency, chemical control has several negative impacts as the selection of resistant individuals due to the continuous use of certain active ingredients, the reduction or elimination of beneficial species, resurgence of pest and the high toxicity of products to applicators. Besides, considering the seriousness of insecticidal toxicity and higher degree of persistence of insecticide residues hinders pest management in chilli crop becoming more sensitive and challenging. To overcome these health hazards and environmental problems in the cultivation of crops, there is an urgent need for developing an effective and eco-friendly pest management approach. The National Academy of Agricultural Sciences (NAAS) recommended a holistic approach involving integrated nutrient management (INM), integrated pest management (IPM) for enhanced input use efficiency, and adoption of region specific promising cropping systems as an alternative organic farming strategy for India and to begin with the practice of organic farming should value crops like spices, medicinal plants, fruits, and vegetables (Bhattacharya and Chakraborty, 2005). Among the various components involved, induced plant resistance to pests can contribute substantially. Through the addition of organic sources of nutrients and amendments, the production of defensive chemicals in plant increases that influence the development and survival of crop pests. So organic amendments provide an ecotechnological stability in pest management and are a vital component of sustainable agriculture. Keeping this in view, the present investigation was carried out to develop ecofriendly management module comprising of organic amendments for sustainable management of major pests of chilli.

\section{Materials and Methods}

Two field experiments were conducted to evaluate three different modules in comparison with farmers practice and untreated control at Pannikundu village of Thirumangalam block of Madurai district, during December 2010 - May 2011 and Sevanelyam village of Aundipatty block of Theni district during August 2012 - January 2013 to evaluate three different IPM modules viz., Bio-intensive, recommended and suggestive modules in comparison with farmers practice and control for the management of major pests of chilli in irrigated condition. Each IPM module was laid out in an area of 0.5 acre and module was divided into five regions, considering each one as replicate. Five plants per replication were randomly selected for assessing the pests and natural enemies. 
The thrips and mite population were assessed from three leaves representing the top, middle and bottom portion of the plant in each of the five plants selected randomly from each module on $15,30,45,60,75,90,105$ and 120 DAP and mean population was worked out. The population was expressed in terms of number of thrips / leaf and number of mite / leaf. Ten plants were selected randomly from each plot and scored for LCI visually by following 0-4 scale (Desai et al., 2006). For fruit borers, the numbers of larvae were counted from each of the five plants selected randomly from each module on 45, 60, 75, 90, 105 and 120 DAP and expressed in terms of larvae / plant. The fruit damage was assessed based on bore holes found on the fruits. The per cent fruit damage was worked out by counting total number of fruits per plant and number of fruits damaged per plant on five randomly selected plants from each module at every picking. The population of natural enemies' viz., green lace wings, coccinellids and spiders were assessed on whole plant and the population was expressed in terms of number / plant. The chillies obtained from different IPM modules were dried plot wise and yield was recorded as $\mathrm{kg} \mathrm{ha}{ }^{-1}$. The plant protection measures carried out in different IPM modules were furnished here under.

Biointensive module $\left(\mathbf{M}_{1}\right)$ : Release of Chrysoperla carnea grub @ $10000 \mathrm{ha}^{-1}$, Trichogramma chilonis @ 50,000 ha ${ }^{-1}$ at the time of moth emergence, foliar application of H.a NPV / S.l NPV @ $250 \mathrm{LE} \mathrm{ha}^{-1}$ against respective borers once in seven days after $T$. chilonis release, NSKE 5\%, Bacillus thuringiensis var. kurstaki@ 1.0 kg ha during fruit formation stage.

Adaptive module (Farmer's practice) $\left(\mathbf{M}_{2}\right)$ : Foliar application of dimethoate 30 EC @ $1 \mathrm{ml}$ $\mathrm{l}^{-1}$ for sucking pests at weekly interval, monocrotophos 36 WSC @ $2 \mathrm{ml} \mathrm{l}^{-1}$ at weekly interval against early sucking pests, Dicofol
18.5 EC @ $4 \mathrm{ml} \mathrm{l}^{-1}$ at weekly interval against mites, chlorpyriphos $20 \mathrm{EC} @ 2 \mathrm{ml} \mathrm{l}^{-1}$ at weekly interval against borers, quinalphos 25 EC @ $2 \mathrm{ml} \mathrm{l}^{-1}$ at weekly interval against borers, carbaryl 50 WP @ $2 \mathrm{~g} \mathrm{l}^{-1}$ at fruit formation stage of weekly interval against borers.

Recommended practice $\left(\mathbf{M}_{3}\right)$ : Need based application of dimethoate $30 \mathrm{EC} @ 2 \mathrm{ml} \mathrm{l}^{-1}$ or quinalphos $25 \mathrm{EC} @ 2 \mathrm{ml} \mathrm{l}^{-1}$ or dicofol 18.5 EC @ $2.5 \mathrm{ml} \mathrm{l}^{-1}$ thrice at fortnightly interval for sucking insect, installing pheromone traps for H. armgera and S. litura @ 12 Nos ha ${ }^{-1}$, collection \& destruction of damaged fruits and grown up larvae of $H$. armgera and $S$. litura, foliar application of B.t.k @ $2 \mathrm{~kg} \mathrm{ha}^{-1}$ during fruit formation stage, spray carbaryl 50 WP @ $3 \mathrm{~g} \mathrm{l}^{-1}$ (or) chlorpyriphos $20 \mathrm{EC} @ 3 \mathrm{ml} \mathrm{l}^{-1}$ or Quinalphos 25 EC $2 \mathrm{ml} \mathrm{l}^{-1}$ for borers.

Suggestive module $\left(\mathbf{M}_{4}\right)$ : Seed treatment with Pseudomonas fluorescens @ $10 \mathrm{~g} / \mathrm{kg}+$ Azophos $25 \mathrm{gm} / \mathrm{kg}$ of seed, soil application of FYM @12.5 t ha ${ }^{-1}+$ Azophos@ $2 \mathrm{~kg} \mathrm{ha}^{-1}+$ Silica solubilizing bacteria @ $2 \mathrm{~kg} \mathrm{ha}^{-1}$ as basal and neem cake ( $300 \mathrm{~kg} \mathrm{ha}^{-1}$ ) in 2 splits at 30 and 60 days after planting, foliar application of neem oil 3\%, release of $C$. carnea grub@ $10000 \mathrm{ha}^{-1}$, four release of T. chilonis @ 50,000 $\mathrm{ha}^{-1}$ at weekly interval coinciding with flowering and emergence of moth, foliar application of H.a NPV / S.l NPV @ 250 LE $\mathrm{ha}^{-1}$ once after the last release of $T$. chilonis, NSKE 5\% (two rounds) once at initiation of flowering and another at 50\% flowering, spinosad $48 \mathrm{SC} @ 0.4 \mathrm{ml} \mathrm{l}^{-1}$ during fruit formation.

\section{Control (M5): untreated check}

Foliar application of respective sprays in respective module was imposed based on ETL of sucking pests / fruit borer in module III and IV whereas on the appearance of pests in module I and II. 


\section{Estimation of biochemical profile}

To find out the effect of IPM modules on biochemical profile of chilli imparting resistance / susceptibility to the pests, biochemical analyses were estimated in leaf samples of chilli except capsaicin, which was estimated in fruits. Fresh leaf samples were collected at 60, 90, and 120 DAP from all the IPM modules and analysed for total chlorophyll (Mahadevan and Sridhar, 1986), total phenols (Malick and Singh, 1980), silica (Nayar et al., 1975), reducing sugars (Sadasivam and Manickam, 1992) and Capsaicin content (\%) of red fruits was measured by spectrophotometric method as described by Sadasivam and Manickam (1992).

\section{Estimation of microbial population}

Soil samples from respective IPM modules were collected at 30, 60 and 90 DAT as per protocol to estimate the microbial population. The microbial diversity in the soil samples collected from chilli field was assessed by serial dilution plate technique (Martin, 1950). After this dilution procedure was continued to obtain a dilution of $10^{-6}$. One $\mathrm{ml}$ portions from the solutions $10^{-3}, 10^{-4}$ and $10^{-6}$ were transferred to sterile Petri dishes for plating the fungi, actinomycetes and bacteria. Approximately $15-20 \mathrm{ml}$ of molten cooled agar medium (Martin Rose Bengal Agar medium; Kenknight agar medium; Nutrient agar medium, respectively) were added to the dilutions $10^{-3}, 10^{-4}$, and $10^{-6}$, respectively. The population of fungi, actinomycetes and bacteria in the samples were calculated and expressed as colony forming unit (CFU) per gram of dry soil. Soil microflora were assessed using the formula as suggested by (Rangaswami, 1996).

Mean number of $\mathrm{CFU} \times$ dilution factor

Number of colony forming units $(\mathrm{CFU})=$

Per gram of oven dry soil

\section{Statistical analysis}

Data obtained from the field study were subjected to ANOVA. The data on percentage values and numbers were subject to arcsine and square root transformation before statistical analysis. The field experiments on the efficacy of modules for the management of major insect pests of chilli were conducted in a randomized block design in order to know the interaction between treatments and the means obtained were separated by LSD (Least Significant Difference).

\section{Results and Discussion}

\section{Pests and natural enemies}

In the present study (Table 1), the suggestive module $\left(\mathrm{M}_{4}\right)$ recorded the lowest population of thrips (0.98 / leaf), mite (1.16 / leaf), LCI weight of oven dry soil

(1.15 / plant), larval population of $H$. armigera (0.72 / plant), S. litura (0.52 larvae / plant) and fruit damage (7.31\%), respectively which was significantly different from Recommended module $\left(\mathrm{M}_{3}\right)$ (1.21 and 1.51/ leaf; 1.32 LCI / plant; 0.94 and 0.72 larvae / plant; $9.32 \%$ ) followed by adaptive module $\left(\mathrm{M}_{2}\right)$ (1.36 and 1.74 / leaf; $1.60 \mathrm{LCI} /$ plant; 1.08 and 0.87 larvae / plant; $10.86 \%$ ) while the population of thrips and mite was 1.64 and 2.04 / leaf; 1.72 LCI / plant; larval population of $H$. armigera and S. litura was 1.29 and 1.06 / plant; fruit damage 12.70 per cent in bio-intensive module $\left(\mathrm{M}_{1}\right)$ and 2.99 and 3.38 / leaf; 2.59 LCI / plant; 2.35 and 1.86 larvae / plant; 20.43 per cent in untreated check (Table 1).

There was no significant difference in natural enemy activities between modules. However, 
numerically higher number of Chrysoperla (1.16 / plant), coccinellids (1.11 / plant) and spiders (0.73 / plant) were noticed only in suggestive module $\left(\mathrm{M}_{4}\right)$ indicating its safety followed by bio - intensive module $\left(\mathrm{M}_{1}\right)$ (1.14, 1.06 and $0.66 /$ plant) and control $\left(\mathrm{M}_{5}\right)$ (1.02, 0.98 and $0.56 /$ plant) while it was 0.97 , 0.93 and 0.50 / plant for recommended module $\left(\mathrm{M}_{3}\right)$ and $0.76,0.79$ and 0.39 / plant in farmers practice $\left(\mathrm{M}_{2}\right)$ (Table 2$)$. It is evident that the Suggestive module $\left(\mathrm{M}_{4}\right)$ exhibited a great impact against major pests of chilli viz., $S$. dorsalis, $P$. latus, $H$. armiger, $S$. litura and however it has not suppressed the activity of natural enemies. There is sizeable amount of literature in a row to indicate the several such location specific modules have been developed elsewhere in India, in which various organic inputs were mixed up judiciously for the management of key pests including $H$. armigera on tomato (Ravi et al., 2008), key pests of brinjal (Suresh et al., 2007), key pests of chilli (Gundannavar et al., 2007; Mondal and Mondal, 2012) etc. Also there are literatures to indicate the safety of organic amendments to natural enemies in chilli ecosystem. This is in agreement to the early reports of Subba Rao et al., (2007) who opined that application of neem cake@250 kg + sunn hemp@250 kg and vermicompost @ $750 \mathrm{~kg} / \mathrm{ha}$ in chilli was quite safe to natural enemies. Similarly, the organic soil amendments like vermicompost (1-2 $\left.\mathrm{t} \mathrm{ha}^{-1}\right)$, neem cake $\left(0.5\right.$ to1.0 $\left.\mathrm{t} \mathrm{ha}^{-1}\right)$, biogas spent slurry $\left(1.0 \mathrm{t} \mathrm{ha}^{-1}\right)$ and FYM (12.5 $\left.\mathrm{t} \mathrm{ha}^{-1}\right)$ were found safer to coccinellids as well as Chrysoperla sp in chilli (Ravi kumar, 2004). Patil et al., (2014) reported that organic nutrient and pest management practices when combined recorded higher number of coccinellids and Chrysoperla in chilli.

\section{Bio-chemical constituents}

The mean total chlorophyll content in leaf sample varied significantly between modules which ranged from 0.95 to $1.83 \mathrm{mg} / \mathrm{g}$ of sample. The suggestive module $\left(\mathrm{M}_{4}\right)$ recorded low total chlorophyll (1.47 mg / g) compared to rest of the modules which had higher chlorophyll content (Table 3). Between IPM modules, the total phenol in leaf samples of chilli showed significant variation which ranged from 1.10 to $2.64 \mathrm{mg} / \mathrm{g}$ of sample, the suggestive module $\left(\mathrm{M}_{4}\right)$ recorded the highest mean total phenol $(2.64 \mathrm{mg} / \mathrm{g})$ as compared to minimum of $1.10 \mathrm{mg} / \mathrm{g}$ in control $\left(\mathrm{M}_{5}\right)$ and rest of the modules. Similarly, the mean silica content in leaf sample was highest in suggestive module $\left(\mathrm{M}_{4}\right)(1.62 \%)$ compared to rest of the modules while silica was least in control $\left(\mathrm{M}_{5}\right)$ $(1.07 \%)$. However, with regard to reducing sugars, leaf samples of suggestive module $\left(\mathrm{M}_{4}\right)$ recorded less reducing sugars $(3.35 \mathrm{mg} /$ $\mathrm{g}$ ) as compared to $5.48 \mathrm{mg} / \mathrm{g}$ in control $\left(\mathrm{M}_{5}\right)$, whereas the reducing sugars were low to moderate in rest of the IPM modules. Further, capsaicin content was the highest $(0.48$ per cent) in dry chilli fruit harvested from suggestive module $\left(\mathrm{M}_{4}\right)$, followed by recommended module $\left(\mathrm{M}_{3}\right)(0.42 \%)$, adaptive module $\left(\mathrm{M}_{2}\right)(0.37 \%)$ and bio intensive module $\left(\mathrm{M}_{1}\right)(0.35 \%)$ (Table 3$)$.

Among IPM modules, suggestive module $\left(\mathrm{M}_{4}\right)$ comprising organic sources of nutrients and amendments viz., Farm yard manure, neem cake and biofertilizers (Azosphos, and silica solubilizing bacteria) registered significantly minimum level of total chlorophyll and reducing sugar and higher content of total phenol, silica and capsaicin and thereby exhibited high level of induced resistance against pests of chilli. The present findings is in accordance with reports of Rajendran and Chandramani (2002) who reported that the application of FYM along with neem cake, Azospirillum, phosphobacterium and silica solubilizing bacteria increased the phenol, tannin and silica content while total chlorophyll content 
and total sugars were low which reduced the incidence of aphid (Myzus persicae Sulz.) and thrips (Scirtothrips dorsalis Fab.) in chilli. Chandrasekar (2003) who also reported that lower amount of reducing sugars and high amount of amino acid, total phenol and capsaicin content was observed in FYM @ 12.5 t/ha + Neem cake @ 250 kg/ha + Azospirillum@2 kg/ha+Phosphobacteria@ $2 \mathrm{~kg} / \mathrm{ha}$ treated chilli plants which recorded lesser population of thrips and mites.

The present finding is also in confirmation with the findings of Irulandi et al., (2010) who reported that application of FYM, neem cake, mahua cake, pungam cake and biofertilizer (Azophos) enhanced the production of defensive chemicals viz., silica, phenol and tannin content in coffee leading to induced resistance in terms of antibiosis against berry borer. Bommesha et al., (2012) also reported that application of neem cake and poultry manure resulted in lower level of chlorophyll, protein, reducing sugar and total sugars with increased level of phenol content in pigeon pea reduced the incidence of sucking pests and pod borers. Balasaraswathi et al., (2014) who also reported that application of FYM + neem cake enhanced the production of phenol content in leaves of mulberry which exhibited induced systemic resistance against pink mealy bug. High concentration of capsaicin in chilli fruits was noticed in suggestive module $\left(\mathrm{M}_{4}\right)$ which is in accordance with Venkatesan (2002) who found that FYM + Neem cake + Azospirillum treated plants showed higher concentration of capsaicin due to increase in phenol content.

\section{Soil microflora}

Analysis of soil samples from chilli field, imparted with three different modules revealed that suggestive module $\left(\mathrm{M}_{4}\right)$ registered a maximum bacterial load of 65.16 x $10^{6} \mathrm{CFU} / \mathrm{g}$ of soil. Next to bacterial, the mean fungal load was higher $\left(42.78 \times 10^{3}\right.$ CFU / g of soil) and also highest load of actinomycetes in soil samples was recorded in suggestive module $\left(\mathrm{M}_{4}\right)\left(30.24 \times 10^{4} \mathrm{CFU} / \mathrm{g}\right.$ of soil), which was followed by recommended module $\left(\mathrm{M}_{3}\right)\left(50.02 \times 10^{6}, 35.84 \times 10^{3}, 21.82\right.$ x $10^{4} \mathrm{CFU} / \mathrm{g}$ of soil), farmers practice $\left(\mathrm{M}_{2}\right)$ $\left(46.70 \times 10^{6}, 33.94 \times 10^{3}, 19.63 \times 10^{4} \mathrm{CFU} / \mathrm{g}\right.$ of soil) and bio-intensive module $\left(\mathrm{M}_{1}\right)$ (45.09 $\mathrm{x} 10^{6}, 32.95 \times 10^{3}, 18.56 \times 10^{4} \mathrm{CFU} / \mathrm{g}$ of soil) in contrast to and control $\left(\mathrm{M}_{5}\right)(40.33 \mathrm{x}$ $10^{6}, 29.52 \times 10^{3}, 16.70 \times 10^{4} \mathrm{CFU} / \mathrm{g}$ of soil) (Table 4).

Suggestive module $\left(\mathrm{M}_{4}\right)$ comprising of organic sources of nutrients and amendments registered more bacterial, fungal and actinomycetes population in soil. This is in accordance with the reports of Nambiar et al., (1992) who reported that application of organic sources encouraged the growth and activity of mycorrhizae and other beneficial organisms in the soil and is also helpful in alleviating the increasing incidence or deficiency of secondary and micronutrients and is capable of sustaining high crop productivity and soil health. Similarly, the present finding was in accordance with the reports of Vemana et al., (1999) who observed the maximum increase in bacterial population in farm yard manure treatment.

Further the high bacterial population with the application of FYM was also reported by Parham et al., (2002). The increase in fungal population due to the application of neem cake in the present findings is in agreement with the earlier workers (Goswami, 1993). Ambika (2007) according to whom that basal application of farm yard manure @ $6.25 \mathrm{t} / \mathrm{ha}$ + neem cake@300kg/ha + Azophos@ $1 \mathrm{~kg} / \mathrm{ha}$ was found to be significantly effective in reducing the population of chilli mite which also registered the maximum bacterial colonies $126.50 \times 10^{6}$ and fungal colonies $20.75 \times 10^{3}$ in soil of in chilli ecosystem. 
Table.1 Effect of IPM modules against major pests of chilli (Pooled mean)

\begin{tabular}{|c|c|c|c|c|c|c|c|}
\hline \multicolumn{2}{|r|}{ IPM modules } & \multirow{2}{*}{$\begin{array}{c}\begin{array}{c}\text { Thrips } \\
\text { (No./leaf) }^{+}\end{array} \\
1.64^{*} \\
(1.46)^{\mathrm{d}}\end{array}$} & \multirow{2}{*}{$\begin{array}{c}\text { Mite (No./leaf) }{ }^{+} \\
2.05^{*} \\
(1.60)^{\mathrm{d}}\end{array}$} & \multirow{2}{*}{$\frac{\text { LCI / plant }}{+}$} & \multirow{2}{*}{$\begin{array}{c}\begin{array}{c}\text { H. armigera } \\
\text { (larvae/ plant) }^{+}\end{array} \\
1^{1.29^{*}} \\
(1.34)^{\mathrm{d}}\end{array}$} & \multirow{2}{*}{$\begin{array}{c}\begin{array}{c}\text { S. litura } \\
\text { (larvae/plant) }^{+}\end{array} \\
1.06^{*} \\
(1.25)^{\mathrm{d}}\end{array}$} & \multirow{2}{*}{$\begin{array}{c}\begin{array}{c}\text { Fruit damage } \\
(\%)^{+}\end{array} \\
12.70^{* *} \\
(20.88)^{\mathrm{d}}\end{array}$} \\
\hline $\mathrm{M}_{1}$ & Bio intensive module & & & & & & \\
\hline $\mathrm{M}_{2}$ & Adaptive module & $\begin{array}{c}1.36 \\
(1.36)^{\mathrm{c}}\end{array}$ & $\begin{array}{c}1.74 \\
(1.50)^{\mathrm{c}}\end{array}$ & $1.60^{\mathrm{c}}$ & $\begin{array}{c}1.08 \\
(1.26)^{\mathrm{c}}\end{array}$ & $\begin{array}{c}0.87 \\
(1.17)^{\mathrm{c}}\end{array}$ & $\begin{array}{c}10.86 \\
(19.24)^{\mathrm{c}}\end{array}$ \\
\hline $\mathrm{M}_{3}$ & Recommended module & $\begin{array}{c}1.21 \\
(1.31)^{b}\end{array}$ & $\begin{array}{c}1.51 \\
(1.42)^{b}\end{array}$ & $1.32^{\mathrm{b}}$ & $\begin{array}{c}0.94 \\
(1.20)^{b}\end{array}$ & $\begin{array}{c}0.72 \\
(1.10)^{b}\end{array}$ & $\begin{array}{c}9.32 \\
(17.78)^{b} \\
\end{array}$ \\
\hline $\mathrm{M}_{4}$ & Suggestive module & $\begin{array}{c}0.98 \\
(1.22)^{\mathrm{a}} \\
\end{array}$ & $\begin{array}{c}1.16 \\
(1.29)^{\mathrm{a}} \\
\end{array}$ & $1.15^{\mathrm{a}}$ & $\begin{array}{c}0.72 \\
(1.10)^{\mathrm{a}} \\
\end{array}$ & $\begin{array}{c}0.52 \\
(1.01)^{\mathrm{a}}\end{array}$ & $\begin{array}{c}7.31 \\
(15.69)^{\mathrm{a}} \\
\end{array}$ \\
\hline $\mathrm{M}_{5}$ & Untreated check & $\begin{array}{c}2.99 \\
(1.87)^{\mathrm{e}}\end{array}$ & $\begin{array}{c}3.38 \\
(1.97)^{\mathrm{e}}\end{array}$ & $2.59^{\mathrm{e}}$ & $\begin{array}{c}2.35 \\
(1.69)^{\mathrm{e}}\end{array}$ & $\begin{array}{c}1.86 \\
(1.54)^{\mathrm{e}}\end{array}$ & $\begin{array}{c}20.43 \\
(26.87)^{\mathrm{e}}\end{array}$ \\
\hline & SE d & 0.011 & 0.016 & 0.065 & 0.014 & 0.007 & 0.26 \\
\hline & $\mathrm{CD}$ at $5 \%$ & 0.023 & 0.034 & 0.141 & 0.030 & 0.014 & 0.57 \\
\hline
\end{tabular}

+ Each value is the mean of five replications; $*$ Figures in parentheses are $\sqrt{X}+0.5$ transformed values

** Figures in parentheses are Arc sine transformed values; In a column, means followed by common letter(s) are not significantly different by LSD (P=0.05)

Table.2 Effect of IPM modules on natural enemies in chilli ecosystem (Pooled mean)

\begin{tabular}{|c|c|c|c|c|}
\hline \multicolumn{2}{|r|}{ IPM modules } & $\begin{array}{l}\text { Chrysoperla } \\
\text { (no /plant) }^{+}\end{array}$ & $\begin{array}{l}\text { Coccinellids } \\
{\text { (no /plant })^{+}}^{-}\end{array}$ & $\begin{array}{c}\text { Spider } \\
{\text { (no /plant })^{+}}^{+}\end{array}$ \\
\hline $\mathrm{M}_{1}$ & Bio intensive module & $\begin{array}{c}1.14 \\
(1.28)\end{array}$ & $\begin{array}{c}1.06 \\
(1.25)\end{array}$ & $\begin{array}{c}0.66 \\
(1.07)\end{array}$ \\
\hline $\mathrm{M}_{2}$ & Adaptive module & $\begin{array}{c}0.76 \\
(1.12) \\
\end{array}$ & $\begin{array}{c}0.79 \\
(1.13) \\
\end{array}$ & $\begin{array}{c}0.39 \\
(0.94) \\
\end{array}$ \\
\hline $\mathrm{M}_{3}$ & Recommended module & $\begin{array}{c}0.97 \\
(1.21) \\
\end{array}$ & $\begin{array}{c}0.93 \\
(1.20) \\
\end{array}$ & $\begin{array}{c}0.50 \\
(1.00) \\
\end{array}$ \\
\hline $\mathrm{M}_{4}$ & Suggestive module & $\begin{array}{c}1.16 \\
(1.29) \\
\end{array}$ & $\begin{array}{c}1.11 \\
(1.27) \\
\end{array}$ & $\begin{array}{c}0.73 \\
(1.11) \\
\end{array}$ \\
\hline $\mathrm{M}_{5}$ & Untreated check & $\begin{array}{c}1.02 \\
(1.23)\end{array}$ & $\begin{array}{c}0.98 \\
(1.21)\end{array}$ & $\begin{array}{c}0.56 \\
(1.03)\end{array}$ \\
\hline & SE d & NS & NS & NS \\
\hline & $\mathrm{CD}$ at $5 \%$ & NS & NS & NS \\
\hline
\end{tabular}

* Each value is the mean of five replications; NS - Non significant; Figures in parentheses are $\sqrt{\mathrm{X}}+0.5$ transformed values 
Table.3 Effect of IPM modules on biochemical components in chilli for their resistant to pests

\begin{tabular}{|c|c|c|c|c|c|c|}
\hline & IPM modules & $\begin{array}{c}\text { Total } \\
\text { Chlorophyll } \\
(\mathrm{mg} / \mathrm{g})^{+}\end{array}$ & $\begin{array}{l}\text { Total phenol } \\
(\mathrm{mg} / \mathrm{g})^{+}\end{array}$ & Silica $(\%)^{+}$ & $\underset{(\mathrm{mg} / \mathrm{g})^{+}}{\text {Reducing sugar }}$ & $\begin{array}{l}\text { Capsaicin } \\
\qquad(\%)^{+}\end{array}$ \\
\hline $\mathrm{M}_{1}$ & Bio intensive module & $1.83^{\mathrm{d}}$ & $1.77^{\mathrm{c}}$ & $1.26^{\mathrm{c}}$ & $3.96^{b}$ & $0.35^{\mathrm{c}}$ \\
\hline & Recommended module & $1.66^{\mathrm{c}}$ & $2.07^{\mathrm{b}}$ & $1.38^{\mathrm{b}}$ & $3.66^{\mathrm{c}}$ & $0.42^{\mathrm{b}}$ \\
\hline & Suggestive module & $1.47^{b}$ & $2.64^{\mathrm{a}}$ & $1.62^{\mathrm{a}}$ & $3.35^{\mathrm{d}}$ & $0.48^{\mathrm{a}}$ \\
\hline & Untreated check & $0.95^{\mathrm{a}}$ & $1.10^{\mathrm{d}}$ & $1.07^{\mathrm{d}}$ & $5.48^{\mathrm{a}}$ & $0.28^{\mathrm{d}}$ \\
\hline
\end{tabular}

${ }^{+}$Each value is the mean of five replication

In a column, means followed by common letter(s) are not significantly different by LSD $(\mathrm{P}=0.05)$

Table.4 Effect of IPM modules on the population of soil microflora

\begin{tabular}{|c|c|c|c|c|}
\hline \multicolumn{2}{|r|}{ IPM modules } & $\begin{array}{c}\text { Bacteria } \\
\left(\times 10^{6} \mathrm{CFU} / \mathrm{g} \text { of soil }\right)^{+}\end{array}$ & $\begin{array}{c}\text { Fungi } \\
\left(x 10^{3} \mathrm{CFU} / \mathrm{g} \text { of soil }\right)^{+}\end{array}$ & $\begin{array}{c}\text { Actinomycetes } \\
\left(\times 10^{4} \text { CFU/g of soil }\right)^{+}\end{array}$ \\
\hline $\mathrm{M}_{1}$ & Bio intensive module & $45.09^{\mathrm{c}}$ & $32.95^{\mathrm{c}}$ & $18.56^{\mathrm{c}}$ \\
\hline $\mathrm{M}_{2}$ & Adaptive module & $46.70^{c}$ & $33.94^{\mathrm{c}}$ & $19.63^{\mathrm{c}}$ \\
\hline $\mathrm{M}_{3}$ & Recommended module & $50.02^{b}$ & $35.84^{\mathrm{b}}$ & $21.82^{b}$ \\
\hline $\mathrm{M}_{4}$ & Suggestive module & $65.16^{\mathrm{a}}$ & $42.78^{\mathrm{a}}$ & $30.24^{\mathrm{a}}$ \\
\hline $\mathrm{M}_{5}$ & Untreated check & $40.33^{\mathrm{d}}$ & $29.52^{\mathrm{d}}$ & $16.70^{\mathrm{d}}$ \\
\hline & SE d & 0.0743 & 0.0609 & 0.0393 \\
\hline & $\mathrm{CD}$ at $5 \%$ & 0.1619 & 0.1327 & 0.0856 \\
\hline
\end{tabular}

${ }^{+}$Each value is the mean of five replications

In a column, means followed by common letter(s) are not significantly different by LSD $(\mathrm{P}=0.05)$ 
Table.5 Effect of IPM modules on the yield of dry chilli (pooled mean)

\begin{tabular}{|c|c|c|c|c|}
\hline \multicolumn{2}{|r|}{ Modules } & \multirow{2}{*}{$\begin{array}{c}\begin{array}{c}\text { Yield } \\
(\mathbf{k g} / \mathbf{h a})^{*}\end{array} \\
1489 \\
(38.59)^{\mathrm{d}}\end{array}$} & \multirow{2}{*}{$\begin{array}{c}\begin{array}{c}\text { Yield increase over } \\
\text { control } \\
\text { (kg / ha) }\end{array} \\
379\end{array}$} & \multirow{2}{*}{$\begin{array}{c}\begin{array}{c}\text { Incremental } \\
\text { Benefit cost ratio }\end{array} \\
1: 2.11\end{array}$} \\
\hline $\mathrm{M}_{1}$ & Bio intensive module & & & \\
\hline $\mathrm{M}_{2}$ & Adaptive module & $\begin{array}{c}1650 \\
(40.63)^{c}\end{array}$ & 540 & $1: 2.88$ \\
\hline $\mathrm{M}_{3}$ & Recommended module & $\begin{array}{c}1793 \\
(42.35)^{b}\end{array}$ & 683 & $1: 3.28$ \\
\hline $\mathrm{M}_{4}$ & Suggested module & $\begin{array}{c}1878 \\
(43.34)^{\mathrm{a}} \\
\end{array}$ & 768 & $1: 3.50$ \\
\hline $\mathrm{M}_{5}$ & Control & $\begin{array}{c}1110 \\
(33.32)^{\mathrm{e}}\end{array}$ & - & - \\
\hline & $\mathrm{SE} \mathrm{d}$ & 0.243 & - & - \\
\hline & $\mathrm{CD}$ at $5 \%$ & 0.530 & - & - \\
\hline
\end{tabular}

*Each value is mean of five replications

Figures in parentheses are $\sqrt{ } \mathrm{X}+0.5$ transformed values

In a column, means followed by common letter(s) are not significantly different by LSD $(\mathrm{P}=0.05)$ 
Murali Baskaran et al., (2008) who also reported that application of vermicompost in combination with neem cake, bio-fertilizers and NPK to senna recorded the highest population of soil fungi, bacteria and actinomycetes.

\section{Yield and economics}

Suggestive module $\left(\mathrm{M}_{4}\right)$ recorded the highest dry chilli yield (1878 kg / ha) with $768 \mathrm{~kg}$ increase in yield over untreated check. Recommended module $\left(\mathrm{M}_{3}\right)$ ranked second with an yield of $1793 \mathrm{~kg} / \mathrm{ha}$ and $683 \mathrm{~kg}$ increase over control, while farmers practice $\left(\mathrm{M}_{2}\right)(1650 \mathrm{~kg} / \mathrm{ha} ; 540 \mathrm{~kg})$ and bio intensive module $\left(\mathrm{M}_{1}\right)(1489 \mathrm{~kg} / \mathrm{ha} ; 379 \mathrm{~kg})$ were third and fourth in terms of yield. Based on the incremental benefit cost ratio, the IPM modules were ranked. Among IPM modules, suggestive module $\left(\mathrm{M}_{4}\right)$ has recorded the highest benefit cost ratio of 1:3.50. While considering both effectiveness and economics, the suggestive module $\left(\mathrm{M}_{4}\right)$ stood first indicating its superiority over other modules. Recommended module $\left(\mathrm{M}_{3}\right)$ (1:3.28) ranked next to suggestive module $\left(\mathrm{M}_{4}\right)$ (Table 5).

\section{References}

Ambika, S.R. 2007. Seasonal incidence and eco-friendly management of yellow mite, Polyphagotarsonemus latus (Banks) on chilli, Capsicum annuum (L.). M.Sc. (Ag.) Thesis, Tamil Nadu Agric. Univ., Coimbatore. $127 \mathrm{p}$.

Anonymous. 2014. Indian Horticulture Data Base. National Horticulture Board, Ministry of Agriculture, Govt. of India, Gurgaon. 302p.

Balasaraswathi, S., S.M.H. Qadri, S. Masilamani and Balakrishna, R. 2014. Induced systemic resistance through various organic cakes on the management of pink mealybug, Maconellicoccus hirsutus infesting mulberry. Acta
Biologica Indica, 3(2): 681-685.

Bhattacharya, P. and Chakraborty, G. 2005. Current status of organic farming in India and other countries. Indian J. Fertilizers, 1 (9): 111-123.

Bommesha, B., M.I. Naik, G.P. Mutthuraju, Arati Pannure, Syed Imran and Prashantha, C. 2012. Effect of organic manures on biochemical components of pigeon pea, Cajanus cajan (L.) Millsp. and their impact on the incidence of insect pests. Curr. Biotica, 6(2): 171-180.

Chandrasekar, R. 2003. Bioecology and ecofriendly management of thrips (Scirtothrips dorsalis Hood) and mites (Polyphagotarsonemus latus Banks) on chillies (Capsicum annum Linn.). M.Sc., (Ag) Thesis, Tamil Nadu Agric. Univ., Coimbatore. $132 \mathrm{p}$.

Desai, H.R., K.A. Bandhania, A.J. Patel, M.B. Patel and Rai, A.B. 2006. Screening of chilli varieties / germplasms for resistance to yellow mite, Polyphagotarsonemus latus (Banks) in South Gujarat. Pest Mgt. Hort. Ecosys., 12(1): $55-62$.

Goswami, B.K. 1993. Effect of different soil amendments with neem cake on root knot nematode on soil mycoflora in cowpea rhizosphere. Indian J. Plant Prot., 23(1): 87-89.

Gundannavar, K.P., R.S. Giraddi, K.A. Kulkarni and Awaknavar, J.S. 2007. Devlopment of integrated pest management modules for chilli pests. Karnataka J. Agric. Sci., 20(4): 757- 760.

Mahadevan, A. and Sridhar, R. 1986. Methods of Physiological Plant Pathol., Sivakami Publications, Madras. 328p.

Malick, C.P. and Singh, M.B. 1980. Plant enzymology and histo enzymology. Kalyani Publishers, New Delhi. 286p.

Martin, J.P. 1950. Use of acid, Rosebengal and streptomycin in the plant for estimating soil fungi. Soil Sci., 69: 215.

Mondal, B. and Mondal, P. 2012. Ecofriendly pest management practices for leaf curl complex of chilli (Capsicum annuum L.). J. Biopest, 5(Sup): 115-118.

Murali Baskaran, R.K., S. Senthil Kumaran, 
D.S. Rajavel and Suresh, K. 2008. Effect of organic source of nutrients on defoliator, Catopsilia pyranthe (L.) (Lepidoptera: Pieriidae) of senna. Pest Mgmt. Hort. Ecosyst., 14(2): 99-102.

Nambiar, K.K.M., P.N. Soni, M.R. Vats, D.K. Sehgal and Mehta, D.K. 1992. AICRP on long term fertilizer experiments, Annual Reports 1987-88 and 1988-89, IARI, New Delhi, India.

Nayar, P.K., A.K. Misra and Patnaik, S. 1975. Rapid microdetermination of silicon in rice plant. Plant and Soil, 42: 491-494.

Parham, J.A., S.P. Deng, W.R. Raun and Johnson, G.V. 2002. Long term cattle manure application in soil, it's effect on soil phosphorus levels, microbial biomass and dehydrogenase and phosphatase activities. Biology and Fertility of Soils, 35 (5): 328-337.

Patil, I.D., H.B. Babalad and Patil, R.K. 2014. Effect of organic nutrient and biological pest management practices on insect pests and disease dynamics in organic chilli production system. Int. J. Recent Scientific Res., 5(9): 1524-1528.

Rajaram, K. 1998. Eco-friendly management of sucking pest of chillies. Ph.D. (Ag.) thesis, Tamil Nadu Agric. Univ., Coimbatore. $186 \mathrm{p}$.

Rajendran, R. and Chandramani, P. 2002. Effect of organic sources of nutrients on pests of chillies. In: National Seminar on Recent Trends in Sulphur and Silicon Nutrition of Crops. Madurai, India, 12-13 June, $\mathrm{p}$ 67.

Rangaswami, G. 1996. Agricultural Microbiology. Asia publishing house, London. 413p.
Ravi, M., G. Santharam and Sathiah, N. 2008. Ecofriendly management of tomato fruit borer, Helicoverpa armigera (Hubner). $J$. Biopest., 1(2):134-137.

Ravikumar. 2004. Evaluation of organics and indigenous products for the management of Helicoverpa armigera (Hubner) in chilli. M Sc. (Agri) Thesis, University of Agricultural Sciences, Dharwad

Sadasivam, S. and Manikam, A. 1992. Biochemical methods for agricultural sciences. Wiley Eastern Ltd., New Delhi. $185 \mathrm{p}$.

Subba Rao, A.K., Sammi Reddy and Ramesh, P. 2007. Protecting soil health under conventional agriculture and organic farming. Green Farming, 1(1): 1-9.

Supriya Lamba, Kajal Midha and Shalabh Agrawal. 2015. Export of Spices. International J. Recent Res. Commerce Eco. Manage., 2(4): 256-266.

Suresh, K., R. Rajendran and Usha Rani, B. 2007. Eco-friendly approach for managing major sucking pests of brinjal. J. Ent. Res., 31(1): 19-22.

Vemana, K., K. Sitaramaiah, P.D. Naidu and Reddy. K.S. 1999. Comparative efficacy of organic amendments and nematicides on population dynamics of Tylenchorhynchus brevilineatus, microbial activity, groundnut pod disease and yield. Indian J. Nematol., 29(1): 5968.

Venkateson, B. 2002. Effect of organic manures with Biofertilizers and inorganic fertilizers schedules on growth and quality of chilli (Capsicum annuum L.) cv. K2. M.sc. (Ag.) Tamil Nadu Agric. Univ., Coimbatore. 132 p.

\section{How to cite this article:}

Ravikumar, A., S. Manisegaran, C. Chinniah and Janahiraman, V. 2017. Induced Systemic Resistance through Organic Based IPM Module against Pest Infesting Chilli. Int.J.Curr.Microbiol.App.Sci. 6(5): 1084-1094. doi: https://doi.org/10.20546/ijcmas.2017.605.118 